\title{
IDENTIFICATION OF GENDER-BASED STUDENT MISCONCEPTION USING CRI CERTAINTY OF RESPONSE INDEX IN PHOTOSINTESIS CONCEPT AND PLANT RESPIRATION
}

\author{
Mar'atul Afidah ${ }^{1)}$ dan Rika Mariati ${ }^{2)}$ \\ ${ }^{1) 2)}$ Pendidikan Biologi FKIP Universitas Lancang Kuning \\ email $^{1)}$ : maratulafidah@unilak.ac.id \\ email $^{2)}$ : rikamariati@gmail.com
}

\begin{abstract}
ABSTRAK : Penelitian ini bertujuan untuk mengetahui tingkat miskonsepsi siswa berdasarkan gender menggunakan Certainty of Respons Index (CRI) pada konsep fotosintesis dan respirasi tumbuhan di kelas VII MTs Darul Muqomah Pekanbaru T.A 2018/2019. Penelitian ini dilaksanakan pada semester ganjil bulan November 2018. Metode penelitian yang digunakan adalah deskriptif kuantitatif dalam bentuk analisis deskriptif non-statistik. Sampel penelitian yang yaitu siswa kelas VII-1 (putra) berjumlah 28 siswa dan kelas VII-2 (putri) berjumlah 21 siswa dengan total sampel 49 siswa, dengan teknik total sampling. Teknik pengumpulan data ini diperoleh dari hasil konsepsi siswa putra dan siswa putri dari pemberian tes berupa pilihan ganda dengan menggunakan lembar jawaban Certainty of Respons Index (CRI) dengan skala keyakinan 0-5. Miskonsepsi konsep fotosintesis dan respirasi tumbuhan siswa putra sebesar 36,49\% dengan kategori sedang dan siswa putri sebesar 30,23\% dengan kategori sedang.
\end{abstract}

Kata kunci: miskonsepsi, gender, Certainty of Respons Index (CRI), fotosintesis dan respirasi tumbuhan

ABSTRACT : This study aims to determine the level of student misconception based on gender using the certainty of index response on the concept of photosynthesis and plant respiration in class VII MTs Darul Muqomah Pekanbaru A.Y 2018/2019. This research was conducted in the odd semester in November 2018. The research method used was quantitative descriptive in the form of descriptive non-statistical analysis. The research sample used was class VII-1 (male) students totaling 28 students and class VII-2 (daughter) totaling 21 students with a total sample of 49 students, with total sampling technique. This data collection technique was obtained from the conception of male students and female students from giving a multiple choice test by using the certainty of index response sheet with a 0-5 confidence scale. Misconceptions concepts of photosynthesis and plant respiration male students by $36,49 \%$ (moderate) and female students by 30,23\% (moderate).

Keywords: misconception, gender, certainty of index response, photosynthesis and plant respiration 


\section{PENDAHULUAN}

Pendidikan merupakan salah satu faktor penting dalam kehidupan kita sebagai manusia. Pendidikan dapat diartikan sebagai sebuah proses dengan metode-metode tertentu sehingga orang memperoleh pengetahuan, pemahaman, dan cara bertingkah laku yang sesuai dengan kebutuhan (Syah, 2010). Pendidikan yang berkualitas akan menghasilkan manusia-manusia yang memiliki kemampuan berpikir kritis, kreatif, inovatif, bertanggung jawab, dan memiliki keterampilan serta memiliki budi pekerti yang baik. Namun, pendidikan yang kurang berkualitas akan menjadi masalah bagi dunia pendidikan itu sendiri, salah satunya yaitu dalam pembelajaran yang sering terjadi kesalahpahaman terhadap konsepkonsep ilmiah.

Pembelajaran merupakan salah satu proses dalam pendidikan yang kompleks dan melibatkan berbagai aspek yang saling berkaitan. Dalam proses pembelajaran melibatkan tiga aspek penting yaitu pedagogis, psikologis, dan didaktis. Pada aspek psikologis siswa memiliki taraf perkembangan berbeda dan dalam proses belajarnya bervariasi, seperti belajar menghapal, belajar keterampilan motorik, belajar konsep dan belajar sikap. Maka seorang guru diharapkan memahami siswanya dengan berbagai keunikannya serta perbedaan agar mampu membantu dalam menghadapi kesulitan belajar (Mulyasa, 2005).

Belajar adalah suatu proses usaha yang dilakukan seseorang untuk memperoleh suatu perubahan tingkah laku yang baru secara keseluruhan, sebagai hasil pengalamannya sendiri dalam interaksi dengan lingkunganya (Slameto, 2003). Menurut Arsyad (2002) belajar adalah suatu usaha kompleks yang terjadi pada setiap orang sepanjang hidupnya yang terjadi karena adanya interaksi antara seseorang dan lingkunganya, oleh karena itu belajar dapat terjadi kapan saja dan dimana saja yang ditandai dengan perubahan tingkah laku yang disebabkan oleh perubahan pemahaman, keterampilan, dan sikap.

Salah satu fokus fundamental dalam belajar adalah mengajarkan 
mengenai konsep-konsep ilmiah karena konsep inilah yang akan menjadi fondasi bagi pengetahuan ilmiah. Namun, dalam mempelajari suatu konsep pada awalnya memiliki pemahaman konsep yang berbeda dengan pengetahuan ilmiah yang diterima pada saat ini, bahkan ada yang mengalami miskonsepsi.

Ada lima faktor yang menyebabkan miskonsepsi yaitu siswa, guru, buku teks, konteks dan metode mengajar (Suparno, 2005). Kelima faktor tersebut sangat penting untuk diperhatikan dalam pelaksanaan pembelajaran yang akan menghasilkan peserta didik yang memiiki konsep secara benar. Kesalahan miskonsepsi yang mereka terima sangat berbahaya karena akan diteruskan dari generasi kegenerasi melalui proses pembelajaran.

Siswa yang menyadari miskonsepsi yang dialaminya, akan lebih mudah untuk merubah dan memperbaiki miskonsepsinya. Siswa juga akan mampu membentuk koneksi konsep dengan sendirinya. Selain itu, siswa akan mudah memutuskan mana yang benar dan mana yang salah tentang suatu konsep. Selanjutnya, siswa juga bisa mengkonstruksi dan merekonstruksi ulang konsepsinya secara aktif. Sebelum diperbaiki, miskonsepsi harus terlebih dahulu diidentifikasi. Identifikasi miskonsepsi diperlukan dalam mengembangkan strategi untuk membentuk pengetahuan konsep yang benar pada masingmasing siswa (Murni, 2013).

Siswa laki-laki dan perempuan memiliki peluang yang sama untuk mengalami miskonsepsi. Prestasi pada bidang biologi siswa perempuan menunjukan hasil lebih unggul dari siswa laki-laki, hal ini dikarenakan siswa perempuan memiliki kemampuan lebih baik dalam membaca dan menulis (Ramdiah, 2014). Dari hal tersebut dapat diduga terdapat perbedaan tingkat miskonsepsi berdasarkan gender. Oleh karena itu, pada penelitian ini dikaji mengenai tingkat miskonsepsi berdasarkan gender sehingga lebih lanjut guru dapat mengetahui kecenderungan miskonsepsi pada siswa lelaki dan perempuan dan menyajikan kegiatan belajar mengajar yang membantu meningkatkan kemampuan siswa 
lelaki dan perempuan serta mengurangi miskonsepsi pada siswa laki-laki dan perempuan. Pola pemisahan rombongan belajar antara siswa laki-laki dan perempuan diterapkan salah satu sekolah di Pekanbaru MTs Darul Muqomah.

Miskonsepsi berbeda dengan istilah tidak tahu konsep. Untuk mengidentifikasi perbedaan tersebut diperlukan suatu instrumen yaitu Certainty of Response Index (CRI). Teknik CRI yang telah dikembangkan oleh Hasan, et al (1999) merupakan teknik yang sederhana dan efektif untuk mengukur miskonsepsi yang terjadi. Teknik Certainty of Response Index (CRI) bisa digunakan untuk mengetahui siswa yang tahu konsep, tidak paham konsep dan yang mengalami miskonsepsi. Nilai CRI yang rendah menunjukkan adanya penebakan sedangkan nilai yang CRI tinggi menunjukkan responden memiliki tingkat kepercayaan diri (confidence) yang tinggi terhadap jawabannya. Dalam keadaan ini, jika jawaban responden benar, artinya tingkat keyakinan yang tinggi akan kebenaran konsepnya telah teruji (justified) dengan baik. Akan tetapi, jika jawaban responden salah, hal tersebut menjadi suatu indikator terjadinya miskonsepsi. Permasalahan tentang miskonsepsi yang sering ditemui dalam pembelajaran IPA di sekolah adalah kesulitan dalam memahami konsepkonsep biologi yang bersifat abstrak dan sulit untuk dipahami baik yang diperoleh dari peserta didik, pendidik maupun dalam buku ajar. Selain itu, penggunaan istilah-istilah yang kurang dikenal bahkan tidak sama sekali dalam menjelaskan atau mendefinisikan konsep baru bisa memicu terjadinya miskonsepsi (Dahar, 1996).

Konsep fotosintesis dan respirasi tumbuhan merupakan salah satu konsep yang dipelajari dalam pembelajaran IPA. Konsep fotosintesis dan respirasi tumbuhan ini merupakan salah satu konsep yang memiliki tingkat kesulitan yang cukup tinggi karena memiliki banyak penjelasan yang bersifat abstrak, sehingga membutuhkan usaha yang sedikit lebih berat dari siswa untuk memahaminya. Pernyataan tersebut didukung oleh hasil penelitian 
Cokadar (2012) yang menyatakan bahwa beberapa siswa sering mengalami miskonsepsi yang cenderung salah pada konsep fotosintesis dan respirasi tumbuhan. Terjadinya miskonsepsi ini tentunya tidak terlepas dari peranan guru. Oleh karena itu, diperlukan adanya identifikasi miskonsepsi pada konsep fotosintesis dan respirasi tumbuhan yang terjadi pada siswa, sehingga dapat ditentukan metode pembelajaran yang tepat agar dapat mengatasi miskonsepsi tersebut dan mengganti miskonsepsi dengan konsep yang benar.

Berdasarkan permasalahan tersebut maka perlu dilakukan penelitian "Identifikasi Miskonsepsi Siswa Berdasarkan Gender Menggunakan Certainty of Response Index (CRI) Pada Konsep Fotosintesis dan Respirasi Tumbuhan Di Kelas VII MTs Darul Muqomah Pekanbaru" yang bertujuan untuk mengetahui tingkat miskonsepsi siswa berdasarkan gender menggunakan Certainty of Response Index (CRI).

\section{METODE PENELITIAN}

Metode yang digunakan dalam penelitian ini deskriptif kuantitatif dalam bentuk analisis deskripstif non-statistik. Apabila data dari hasil penelitian deskriptif telah terkumpul maka data selanjutnya diklasifikasikan menjadi dua kelompok, yaitu data kuantitatif yang berbentuk angka-angka dan data kualitatif yang dinyatakan dalam kata-kata atau simbol. Dalam tahapan analisis ini, data kualitatif yang berbentuk kata-kata tersebut disisihkan untuk sementara, karena akan sangat berguna untuk menyertai dan melengkapi gambaran yang diperoleh dari analisis data kuantitatif. Pada dasarnya mengubah data hasil penelitian ke dalam bentuk deskriptif angka-angka yang sudah dipahami, misalkan dalam bentuk persentase (Hikmawati, 2017). Populasi dalam penelitian ini adalah seluruh siswa kelas VII MTs Darul Muqomah Pekanbaru, yang berjumlah 49 siswa yang terdiri dari kelas VII-1 (Putra) sebanyak 28 siswa dan VII-2 (Putri) sebanyak 21 siswa sehingga totalnya adalah 49 siswa. Teknik pengambilan sampel 
dalam penelitian ini adalah Total Sampling (Sugiyono, 2007). Teknik pengumpulan data dengan menggunakan tes diagnostik/ pemberian tes berupa pilihan ganda dengan menggunakan lembar jawaban model Certainty of Response Index (CRI) kepada subjek. Instrument yang digunakan terlebih dahulu divalidasi melalui software Anates. Pada instrument CRI ini siswa diberikan gambaran mengenai tingkat keyakinan responden terhadap jawaban yang di pilihnya. CRI biasanya didasarkan pada skala enam $(0,1,2,3,4,5)$ seperti pada tabel di bawah ini:

Tabel.3.1

CRI Skala 6 dan Kriterianya

\begin{tabular}{|l|l|}
\hline CRI & Kriteria \\
\hline 0 & Jawaban ditebak secara total \\
\hline 1 & Hampir menebak \\
\hline 2 & Tidak yakin \\
\hline 3 & Yakin benar \\
\hline 4 & Hampir pasti benar \\
\hline 5 & Pasti benar \\
\hline
\end{tabular}

Sumber : Hasan, et al (1999).

Data yang diperoleh dari hasil tes diagnostic CRI. Jawaban siswa dinilai dengan kriteria penilaian berikut:

Tabel. 3.2

\section{Ketentuan CRI untuk}

Membedakan antara Tahu
Konsep, Miskonsepsi, dan Tidak

Tahu Konsep.

\begin{tabular}{|c|c|c|}
\hline $\begin{array}{l}\text { Kriteria } \\
\text { jawaban }\end{array}$ & $\begin{array}{l}\text { CRI } \\
\text { rendah }(<2,5)\end{array}$ & $\begin{array}{l}\text { CRI tinggi } \\
(>2,5)\end{array}$ \\
\hline $\begin{array}{l}\text { Jawaban } \\
\text { benar }\end{array}$ & $\begin{array}{ll}\text { Tidak tahu } \\
\text { konsep }\end{array}$ & $\begin{array}{l}\text { Menguasai } \\
\text { konsep } \\
\text { dengan baik }\end{array}$ \\
\hline $\begin{array}{l}\text { Jawaban } \\
\text { salah }\end{array}$ & $\begin{array}{ll}\text { Tidak tahu } \\
\text { konsep }\end{array}$ & $\begin{array}{l}\text { Kemungkinan } \\
\text { terjadi } \\
\text { miskonsepsi }\end{array}$ \\
\hline
\end{tabular}

Sumber : Hasan, et al (1999).

Jawaban siswa dianalis dengan menggunakan teknik CRI. Merujuk pada jawaban benar dan salah dari siswa dan merujuk pada klasifikasi CRI yang dilengkapi dengan skala keyakinan terhadap jawaban. Jawaban siswa berdasarkan kategori kriteria CRI dipresentasekan berdasarkan kelompok kategori paham, miskonsepsi dan tidak paham, dihitung dengan menggunakan rumus :

$\mathrm{P}=\frac{f}{N} \times 100 \%$

Keterangan :

$\mathrm{P}$ : Angka presentase kelompok

f : Jumlah siswa tiap kelompok

$\mathrm{N}$ : jumlah individu (Jumlah seluruh siswa yang menjadi subjek penelitian)

Presentase berdasarkan kelompok kategori paham, 
miskonsepsi dan tidak paham dapat dilihat pada Tabel berikut ini :

Tabel 3.3

Kategori Tingkat

\section{Miskonsepsi}

\begin{tabular}{|c|c|}
\hline Persentase & Kategori \\
\hline $0-30 \%$ & Rendah \\
\hline $31-60 \%$ & Sedang \\
\hline $61-100 \%$ & Tinggi \\
\hline
\end{tabular}

Sumber : Hasan, et al (1999).

\section{HASIL DAN PEMBAHASAN}

Menjajaki sejauh mana efektivitas penggunaan CRI, peneliti telah melakukan ujicoba penelitian untuk mengidentifikasi terjadinya miskonsepsi pada konsep fotosintesis dan respirasi tumbuhan, yang mengalami kejadian konsepsi pada siswa putra berjumlah 644, dan pada siswa putri berjumlah 483, dengan total kejadian berjumlah 1.127 kejadian yang berasal dari penghitungan jumlah siswa dikali dengan jumlah soal. Berdasarkan hasil penelitian diperoleh data-data yang terdiri dari 4 kategori pemahaman CRI yaitu siswa yang paham konsep (PK), tidak paham konsep (TPK), miskonsepsi (MS). Dalam prosesnya, untuk mengumpulkan data-data yang akan digunakan dalam menjawab permasalahan penelitian, maka setiap siswa selain menjawab setiap soal yang diberikan siswa juga menilai tingkat keyakinan CRI pada setiap jawaban yang dipilihnya pada setiap soal yang diberikan. Berikut ini adalah diagram batang persentase distribusi tes CRI siswa putra.

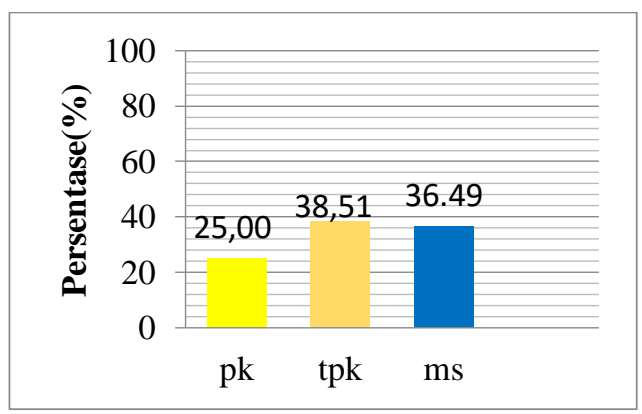

Keterangan

PK : Paham konsep

TPK : Tidak paham konsep

MS : Miskonsepsi

Berdasarkan Gambar di atas hasil tes diagnostik dengan menggunakan teknik CRI menunjukkan bahwa jumlah siswa yang paham konsep sebesar 25,00\%, siswa tidak paham konsep sebesar $38,51 \%$, dan siswa yang mengalami miskonsepsi sebesar 36,49\% dengan kategori sedang. Berikut adalah distribusi hasil tes CRI siswa kelas VII-2 putri. Di bawah ini adalah 
diagram batang persentase distribusi tes CRI siswa putri.

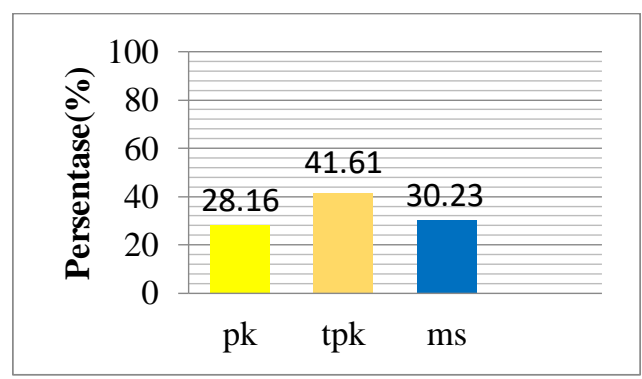

Keterangan:

PK : Paham konsep

TPK : Tidak paham konsep

MS : Miskonsepsi

Berdasarkan Gambar diagram batang persentase distribusi tes CRI siswa putri, menunjukkan bahwa jumlah siswa yang paham konsep $28,16 \%$, siswa tidak paham konsep sebesar 41,61\%, siswa yang mengalami miskonsepsi sebesar $30,23 \%$ dengan kategori sedang. Berikut adalah diagram batang persentase miskonsepsi siswa putra pada tiap indikator.

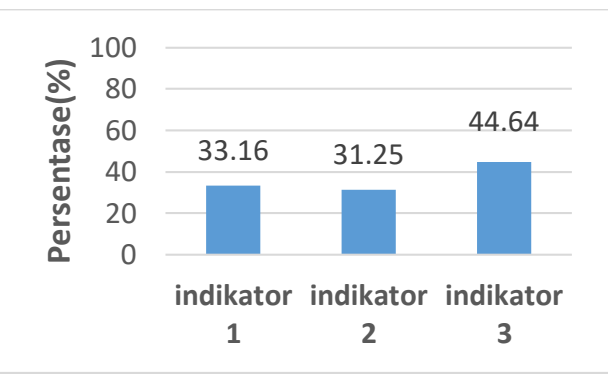

Pada Gambar diagram batang persentase miskonsepsi siswa putra pada tiap indikator, diketahui indikator yang paling banyak mengalami miskonsepsi adalah indikator menentukan zat yang digunakan pada proses respirasi dan organel yang terlibat didalamnya, sebesar 44,64\% kategori sedang, dan indikator yang terendah yaitu menyatakan pembuktian percobaan mengenai fotosintesis dan organel yang terlibat sebesar 31,25 dengan kategori sedang. Berikut diagram batang miskonsepsi siswa putri pada tiap indikator.

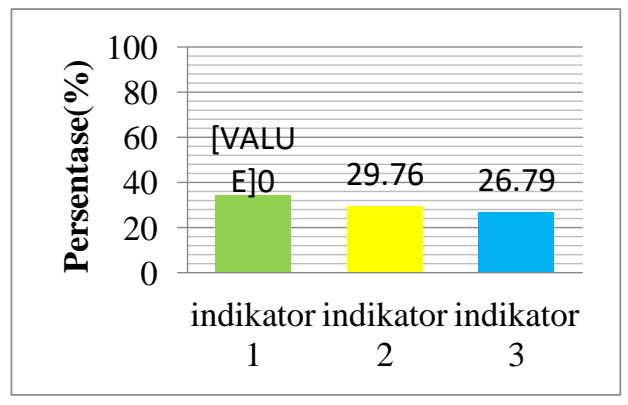

Pada Gambar di atas secara keseluruhan hasil tes diagnostik dengan menggunakan tes pilihan ganda dengan menggunakan CRI menunjukkan bahwa siswa mengalami miskonsepsi pada tiap indikator. indikator yang paling banyak mengalami miskonsepsi adalah indikator tentang Menentukan zat yang digunakan pada proses respirasi dan organel yang terlibat didalamnya, sebesar 
$34,70 \%$ dengan kategori sedang, dan tingkat miskonsepsi terendah adalah indikator menyatakan pembuktian percobaan mengenai fotosintesis dan organel yang terlibat sebesar $29,76 \%$ dengan kategori rendah. Persentase miskonsepsi siswa putra dan putri pada tiap butir soal disajikan pada diagram batang berikut ini:

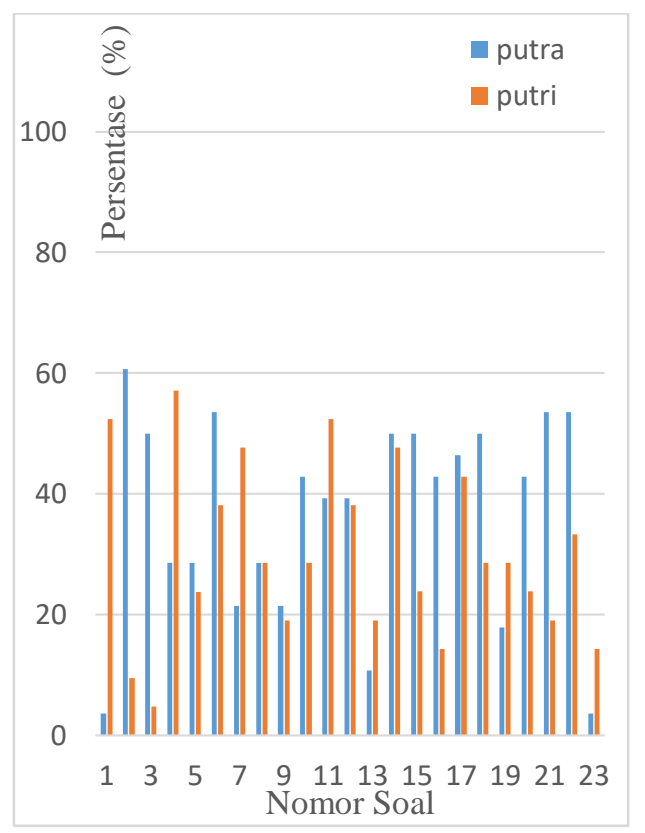

Berdasarkan Gambar di atas, persentase miskonsepsi pada konsep fotosintesis dan respirasi tumbuhan pada tiap butir soal, miskonsepsi telah dialami siswa putra dan putri, miskonsepsi tertinggi pada siswa putra terjadi pada butir soal nomor 2 dengan persentase sebesar $60,71 \%$ dengan kategori tinggi, dan persentase tingkat miskonsepsi terendah terjadi pada butir soal nomor 1 dan 23 dengan persentase sebesar $3,57 \%$ dengan kategori rendah, sementara pada siswa putri miskonsepsi tertinggi terjadi pada butir soal nomor 4 dengan persentase sebesar $57,14 \%$ dengan kategori sedang, dan persentase tingkat miskonsepsi terendah terjadi pada butir soal nomor 3 dengan persentase sebesar 4,76 dengan kategori rendah.

\section{Pembahasan}

Berdasarkan hasil penelitian identifikasi miskonsepsi siswa berdasarkan gender menggunakan CRI pada konsep fotosintesis dan respirasi tumbuhan mengalami miskonsepsi pada semua indikator. Menurut Hasan, et al (1999) miskonsepsi adalah tingkat keyakinan (certainty) siswa yang tinggi terhadap suatu konsep yang dinilai salah. Menurut Suparno (2005) ada lima faktor yang menyebabkan miskonsepsi yaitu siswa, guru, buku teks, konteks dan metode mengajar. Penyebab yang berasal dari siswa dapat terdiri dari 
berbagai hal seperti prakonsepsi awal, kemampuan, tahap perkembangan minat, cara berpikir dan teman lain. Penyebab kesalahan dari guru dapat berupa ketidakmampuan guru, kurangnya penguasaan bahan, cara mengajar yang tidak tepat atau sikap guru dalam berelasi dengan siswa yang kurang baik. Miskonsepsi yang disebabkan oleh salah mengajar agak sulit dibenahi karena siswa merasa yakin bahwa yang diajarkan guru itu benar. Penyebab miskonsepsi dari buku terdapat pada penjelasan atau uraian yang salah dalam buku tersebut. Konteks, seperti budaya, agama dan bahasa sehari-hari juga mempengaruhi miskonsepsi siswa. Sedangkan metode mengajar hanya menekankan pada kebenaran satu segi, sering memunculkan salah pengertian siswa.

Berdasarkan analisis miskonsepsi siswa pada indikator satu, yaitu menentukan zat yang diperlukan dan dihasilkan pada saat proses fotosintesis dan faktor yang mempengaruhinya, pada indikator ini siswa putra mengalami miskonsepsi dengan total rerata persentase
$33,16 \%$ (sedang), sementara pada siswa putri dengan total rerata persentase $\quad 34,70 \% \quad$ (sedang), penyebab terjadinya miskonsepsi yaitu berasal dari siswa itu sendiri, karena kebanyakan siswa hanya menghafal materi sesuai dengan yang ditulis dibuku atau penjelasan yang disampaikan oleh guru tanpa memahami maknanya. Hal ini sesuai dengan penelitian yang dilakukan oleh Puspitasari (2017) tentang miskonsepsi siswa pada materi fotosintesis, yang disebabkan 3 faktor yang mempengaruhi miskonsepsi siswa, yaitu siswa tidak belajar di rumah sebelum mengikuti pelajaran biologi, siswa menganggap bahwa pelajaran biologi adalah pelajaran hafalan yang tidak berkaitan dengan kehidupan nyata, siswa membayangkan kejadian yang dialami terkait dengan materi mesikupun guru baru saja menjelaskannya (prakonsepsi) dapat disimpulkan bahwa terjadinya miskonsepsi berasal dari siswa itu sendiri.

Pada indikator dua, yaitu menyatakan pembuktian percobaan mengenai fotosintesis dan organel 
yang terlibat, pada indikator ini siswa putra mengalami miskonsepsi dengan total rerata persentase $31,25 \%$ (sedang), sementara pada siswa putri mengalami miskonsepsi dengan total rerata persentase 29,76\% (rendah). Penyebab terjadinya miskonsepsi yaitu, siswa putri cenderung lebih aktif dalam mencari informasi mengenai materi yang dipelajari, dan mampu mengkonstruksikan pengalamannya sendiri dengan baik, sementara pada siswa putra lebih banyak pasif dalam mencari informasi materi, yang akan menyebabkan pengetahuan yang terkonstruksi akan terputus, pengalaman belajar yang berbeda akan berpengaruh terhadap miskonsepsi yang terjadi. Searah dengan penelitian Ramdiah (2014) bahwa Siswa laki-laki dan perempuan memiliki peluang yang sama untuk mengalami miskonsepsi. Prestasi pada bidang biologi siswa perempuan menunjukan hasil lebih unggul dari siswa laki-laki, hal ini dikarenakan siswa perempuan memiliki kemampuan lebih baik dalam membaca dan menulis.

\section{KESIMPULAN DAN SARAN}

Pada indikator tiga, yaitu menyatakan menentukan zat yang digunakan pada proses respirasi dan organel yang terlibat didalamnya, pada indikator ini siswa putra mengalami miskonsepsi dengan total rerata persentase $44,64 \%$ (sedang), sementara pada siswa putri dengan total rerata persentase $26,79 \%$ (rendah). Hal ini disebabkan oleh minat belajar yang berbeda siswa putra lebih aktif dalam pembelajaran di luar kelas, sementara pada siswa putri lebih aktif dalam proses pembelajaran di dalam kelas. Hal ini dapat diketahui dari proses pembelajaran yang dilakukan oleh siswa. Menurut Suparno (2005) menjelaskan beberapa faktor penyebab lahirnya miskonsepsi yaitu masalah pada prakonsepsi, pemikiran asosiatif, pemikiran humanistik, reasoning yang tidak lengkap, intuisi yang salah, perkembangan kognitif, kemampuan siswa dan minat belajarnya. 


\section{DAFTAR PUSTAKA}

Arsyad.

(2002).

Media

Pembelajaran.

Jakarta:

Grafindo Persada.

Cokadar, Hulusi.

Photosynthesis and Respiration

Processes : Prospective

Teacher's Conception Level.

Education and sceince Journal:

37 (164):82-94

Dahar, Ratna. Willis. (1996). TeoriTeori Belajar. Jakarta: Erlangga.

Hasan, S., D. Bagayoko, D., and Kelley, E. L., (1999). Misconseptions and the Certainty of Response Index (CRI). Phys. Educ. 34 (5) p. 294 - 299.

Hikmawati, F. (2017). Metodologi Penelitian. Depok: Raja Grafindo.

Mulyasa, E. (2005). Menjadi Guru Professional Menciptakan Pembelajaran Kreatif dan Menyenangkan. Bandung: Remaja Rosda Karya.

Murni, Dewi. (2013). Identifikasi Miskonsepsi Mahasiswa pada Konsep Substansi Genetika Menggunakan Certainty of Response Index (CRI). Jurnal Prosiding Semirata FMIPA Universitas Lampung. 205211:

(online).Tersedia:https//fmipa. unila.ac.id. [13 Oktober 2018].
Puspitasari, Pipit. (2017). Identifikasi Miskonsepsi Siswa pada Materi Fotosintesis dan Respirasi Tumbuhan. Pendidikan Biologi. (online). Tersedia:http://digilib.unila.ac.i d.html. [12 Januari 2019].

Ramdiah, S. (2014). Pengaruh Strategi Pembelajaran PQ4R diintegrasikan Peta Konsep dan Gender terhadap Keterampilan Metakoqnitif, Berpikir Kritis, Hasil Belajar Kognitif Biologi, dan Retensi Siswa SMA di Kota Banjarmasin. Malang. Disertasi Tidak diterbitkan. : PPs UM.

Slameto. (2003). Belajar \& Faktorfaktor yang Mempengaruhinya. Jakarta: Rineka Cipta.
Syah, M. (2010). Psikologi Pendidikan dengan Pendekatan Baru. Bandung: Rosdakarya.

Sugiyono. (2007). Metode Penelitian Kuantitatif Kualitatif dan $R \& D$. Bandung: Alfabeta.

Suparno, P. (2005). Miskonsepsi dan Perubahan Konsep dalam Pendidikan Fisika. Jakarta: Grasindo. 